\title{
Building for Modernity in Post Uprising Colonial India: Sanderson's Survey and other Tales of Modern Indian Architecture
}

\author{
Jyoti Pandey Sharma
}

Department of Architecture, Deenbandhu Chhotu Ram University of Science \& Technology Murthal, Haryana, India 131039

Email: jyotip.sharma@gmail.com

\section{ARTICLE INFORMATION}

Received: January 12, 2017

Revised: March 08, 2017

Accepted: April 25, 2017

Published online: July 03, 2017

Keywords:

Hybridity; Mistri; Modernity; Patron; PWD

DOI: http://doi.org/10.15415/cs.2017.51001

\begin{abstract}
The post uprising colonial modern state zealously ushered modernity in the Indian Subcontinent. In the domain of architecture it produced a building frenzy from implementation of urban improvement schemes to raising infrastructure including buildings patronised by the government, Indian rulers and the masses. In a departure from the state's view to impose the Eurocentric, universal idea of modernity as the only legitimate form of architectural expression, the corpus of buildings built at the turn of the century was a hybrid product of entanglement of tradition and modernity. Indeed, the various actors engaged in the production of buildings, from patrons to designers including architects and Mistris (craftsmen) negotiated modernity on their own individual terms in the absence of any established framework. Types of buildings ranged from state buildings for governance to opulent princely palaces to innumerable every day buildings. This Paper examines the many trajectories of architectural expression that prevailed in the Indian Subcontinent at the turn of the century and argues that the notion of modernity was not homogenous and was characterised by hybridity. It further asserts that this extant building corpus should get its due as modern heritage and be conserved today.
\end{abstract}

\section{Introduction}

The post uprising colonial state in the Indian Subcontinent expected the colony to embrace modernity as the vehicle for progress and development. The zeal to modernize percolated from the highest echelons of colonial authority (Klein, Ira 2000). Indeed, Viceroys, in speech after speech urged their Indian subjects to embrace modernity. Decades after the uprising, sufficient progress had been made in this regard and the incumbent Viceroy, Curzon, expressed satisfaction with the state of affairs in a speech delivered at Lucknow on December 13, 1899, on the occasion of a Durbar, a public ceremony to exhibit the might of the state. Curzon stated that 'Everywhere throughout India, I observe an increasing spirit of public activity, and an awakening to the conditions of modern life, the spread of railways, the increase of education, the diffusion of the Press, the construction of public works, the expansion of manufacturing and industrial undertakings, all of these bespeak, the eager yearnings of a fresh and buoyant life' (Raleigh, Sir Thomas 1906). It is worth underscoring that Curzon's speech while dwelling on the emergence of infrastructure, fails to mention buildings as symbols of a rapidly modernizing India. The near absence of architecture from the discourse on the colonial state's perception of modernity, even as buildings were being built on an unprecedented scale both by the state and private enterprise across the Subcontinent, makes the subject worthy of examination. This Paper focuses on the state of architecture in what Scriver has described as 'colonialmodern' Subcontinent, a befitting description applicable to the Indian Subcontinent in the post uprising era from the late $19^{\text {th }}$ to the early decades of the $20^{\text {th }}$ century (Scriver, Peter and Prakash, V. 2007). This period witnessed a building frenzy from commissioning of improvement schemes at city scale to designing of new infrastructure. Contained in its expansive fold were among others, building of roads, canals, dams and railways; devising engineered solutions for water supply and sanitation; and creating a vast network of buildings including schools, colleges, hospitals, museums, parks and libraries, to name some. While infrastructure projects like the railways, canal and road networks, were hailed as icons of modernity by the state including Viceroys in their public speeches, buildings remained in the shadow and were hardly the subject of discussion as paradigms of modernity.

It is asserted that the architecture of this era lies at a critical juncture in the built environment narrative of the Indian Subcontinent, between what architectural historians describe rather generically as colonial architecture and the architecture of post-independent India that is dominated by 
the Eurocentric modernity discourse. The large corpus of buildings of this period finds no place in the former category that tends to be dominated by the building enterprise firstly of the British East India Company and subsequently the Raj while the latter is dominated by notions of modernity emanating from the west under the influence of Walter Gropius, Le Corbusier and Louis Kahn, among others. The paper argues that the notion of modernity in colonial India was not homogenous and was characterised by what Bhaba has called 'hybridity' (Bhaba, Homi K. 1994). It further asserts that hybridity existed in the domain of architecture as well with multiple versions of modernity as the state and indigenes commissioned a large number of buildings in the post uprising era. The paper supports this claim by critically examining a relatively little-known work, by Gordon Sanderson, Superintendent in Archaeological Survey of India (henceforth ASI), that was undertaken at the behest of the London based India Society to assess the state of architecture in India. The work presented a survey of modest, common place buildings built largely in the late $19^{\text {th }}$ and early $20^{\text {th }}$ century by indigenous craftsmen, Mistris, as examples of modern Indian architecture. The inclusion of this corpus of craftsmen designed and executed every day buildings as a representative of modernity in early $20^{\text {th }}$ century, pre-independence India, itself was contested on account of the state's apathetic attitude towards traditional architecture and further due to the state perpetuated schism between the professional i.e. engineer and architect versus the indigenous craftsman, who tended to be unschooled. This state of affairs notwithstanding, both the patrons and the executers of their architectural works indulged in the production of buildings that represented not one but various notions of modernity. By drawing attention to this architectural corpus, the paper underscores that the discourse of modernity in Indian architecture needs to be revisited in light of the sheer diverse ways in which the European ideal was configured in the Subcontinent.

\section{Context}

Modernity in colonial India was far from being simply a colonial import that the state wished to impose on its subjects on its own terms. Indeed, as Gaonkar has argued that modernity with its 'Janus-like character' produced what he calls 'Alternative Modernities' that in turn produced 'combinations and recombination's that are endlessly surprising' (Gaonkar, Dilip P. 2001). Further, he has asserted that 'Non-Western people, the latecomers to modernity' including Indians whose introduction to modernity was an outcome of the colonial enterprise, when faced with modernity do not 'turn inward, one does not retreat, one moves sideways, one moves forward. All of this is creative adaptation' (Gaonkar, Dilip P. 2001). Indeed, Indians in the late $19^{\text {th }}$ and early $20^{\text {th }}$ century straddled two worlds, one defined by the indigenous tradition and the other by a novel metropolitan notion of living. Scholars like Bhaba and Appadurai have argued that encounters between these two disparate entities produced varied forms of expression resulting in a complex overlay of traditionalism and Modernity marked by hybridity (Appadurai, Arjun 1996 \& Bhaba, homi K. 1994). These multi-layered, entangled versions of the tradition-modernity combined challenged the universality that formed the essence of the idea of modernity as emerging in the west and were marked by the acceptance, adaptation and even rejection of the universal modernist ideal as an import from the west.

This hybridity resulting from Gaonkar's 'creative adaptation' was evident also in architecture among other disciplines as the Subcontinent was engaged in an ambitious building programme in the post uprising decades (Metcalfe, thomas R. 1989 \& Volwahsen, A. 2004). As Scriver has rightly asserted the building scene of colonial South Asia was not just a provincial theatre for the playing out of metropolitan ideas and fashions. In complex and often contradictory ways, the architectural and engineering hubris of modern Britain was engaged in and mediated by the peculiar theatrics of the colonial-modern situation. In the process, the cultural norms, aspirations and delusions of both the colonizers and the colonized were materially and symbolically embodied in the walls and spaces of their buildings (Scriver, Peter and Prakash, V. 2007). Indeed, the essence of Scriver's 'colonial-modern situation' was defined by encounters between the metropole and the indigenous tradition that resulted in the production of space marked by the modern-traditional duality. Recent scholarship on architecture has rejected the notion of a single universal idea of modernity, and instead addressed the myriad responses of the indigenes to the changes being ushered by colonisation in the urban landscape of the Subcontinent's cities, terming them 'Indigenous Modernities' that were characterised by complexity and contradiction (Hosagrahar, Jyoti 2005). This argument fits within the larger modernity framework described by Gaonkar as 'Everywhere, at every national/ cultural site, modernity is not but many; modernity is not new but old and familiar; modernity is incomplete and necessarily so' (Gaonkar, Dilip P. 2001). It is therefore only to be expected that modernity in colonial Indian Subcontinent would be a complex and contested phenomenon.

Further, in more architecturally empirical terms, in the absence of any framework as to how the duality between modernity and tradition was to be negotiated, it was left to the professionals and patrons to devise strategies for modernizing their building enterprises in ways they deemed appropriate. 
The former included military engineers working for the Public Works Department (henceforth PWD), a handful of architects from Britain, practicing in India, as well as Mistris, who handled a bulk of the architectural commissions. The professionals, dominated by engineers and with only a handful of architects, were products of an institutionalized pedagogical framework and by extension subscribed predominantly to the Eurocentric version of modernity (Sandes, E. W. C. 1935). The Mistris, on the other hand, were unschooled, who negotiated modernity on their own terms against the backdrop of a living, indigenous building tradition. There existed a gap between the professionals and the Mistris that the colonial state made no attempts to bridge resulting in what Scriver calls the 'perceived conflict in the architecture of colonial-modern India between the traditional building crafts of the subcontinent and modern European design principles and methods' (Scriver, Peter and Prakash, V. 2007). It would not be an exaggeration to state that the British government did not acknowledge the contribution of Mistris at all in the building of post uprising modern India and constantly attempted to negate their worth as professionals (Tillotson, Giles H. R. 1989). Like the builders, the patrons too were a heterogeneous entity. The major patron of architectural works in post uprising India was the colonial government whose outlook towards architecture was shaped by the political framework and predominantly tended to veer towards metropolitan influences underscored by $19^{\text {th }}$ century historicism and eclecticism, and further the government relied on the PWD and British architects for the implementation of its building programme, leaving no room for the Mistris. Another influential group of patrons included Indian rulers, who ruled around six hundred odd princely states with some degree of autonomy even as their allegiance remained cemented with the British Crown. The colonial state shared a complex relationship with the Indian rulers, regarding them as power hungry despots, on the one hand, while also conceding that they were the most suitable conduits for ushering modernity (Metcalfe, Thomas R. 1989). Even as Indian rulers were the poster boys of the colonial state's modernizing mission, their credentials as aspiring progressive men never in doubt, their acceptance of modernity was varied. States like Gwalior and Baroda launched the modernization programme enthusiastically focusing on industrial development, commercial growth and governance based on western ideals. Others like the Rajputana states espoused modernity with a degree of caution while upholding traditional ideals (Copland, Ian 1997 \& Sachdev, V. 2012). It would hardly be an exaggeration to suggest that a bulk of the building enterprise was centered in the Indian states with the rulers steering the architectural agenda and relying on the PWD, British architects and unlike the colonial regime were not averse to hiring Mistris for their architectural enterprise. This is also evident from Sanderson's survey that drew on the states of north and central India to seek specimens of modern Indian buildings as has been discussed below. The largely unsung patrons were ordinary people commissioning Mistris to build their everyday buildings that Sanderson was asked to survey. With such a diverse group, it was only to be expected that modernity in architecture would chart an unconventional path first in the absence of any single framework and second due to the multiple ways in which the idea of modernity was interpreted by both patrons and builders.

Decades after the uprising, the urban landscape of cities across the Indian Subcontinent began to undergo change under the influence of metropolitan practices (Glover, William J. 2007, Gupta, Narayani 1981 \& Oldenburg, Veena T. 1984). In this scenario, reliance on the most powerful symbol of modernity i.e. industrial technology was a foregone conclusion, even as the extent to which it was put to use varied by the various actors involved as discussed above. The urban space in most cities, notably capitals of Indian states, was marked by a metropole inspired industrial-utilitarian landscape at the core of which lay the spatial ensemble of the Railway Station-Factory-MuseumLibrary-Club-Menagerie-Public Park combine, even as the urban infill was marked by an assortment of architecturally hybrid buildings (Hosagrahar, Jyoti 2005 \& Pandey Sharma, J. 2015) (Fig.1). While builtform types in this central ensemble like the railway station and factory were products of the Industrial Revolution and therefore dependent on industrial technology, others like the library and museum also began to show receptivity towards industrial products in construction. Industrial products commonly used in construction included among others structural steel, concrete, ceramic tiles, stained glass panels, corrugated galvanised iron sheets as well as cast and wrought iron brackets, balconies, staircase, and balustrades. These were initially imported from Britain and subsequently were manufactured in the Subcontinent. Gradually, industrial technology found takers among indigenes, both Mistris and plebeian patrons, whose negotiation with novel construction materials and design elements resulted in the creation of spatial organizations marked by a modern-traditional hybridity. These included built form types that were not a product of metropolitan culture but were indigenous and included among others residences like Havelis (mansions), memorials, shops and religious buildings (Hosagrahar, Jyoti 2001) (Fig. 2). Even as a large majority sought industrial technology to solve their architectural problems, there existed an alternative view that argued for state patronage of the centuries old, craft based building tradition of the Mistri, that was untouched by industrialization (Tillotson, Giles H. R. 1989). This view was advocated by British individuals 
like John Lockwood Kipling; Samuel Swinton Jacob; F. S. Growse and E. B. Havell, and later Claude Batley, who constitued what came to be popularly referred to as the pro-craft lobby. This lobby published works on the Indian architectural tradition to draw attention of the state towards the rich construction heritage of the Subcontinent (Batley, Claude 1960, Growse, F. S. 1885, Havell, E. B. 1913 \& Jacob, S. S. 1890). This perception also attracted intellectuals in Britain, like the India Society, who also lobbied with the colonial government to promote the Subcontinent's indigenous craft based tradition. In such a scenario, it was only to be expected that the building tradition in 'colonialmodern' India would charter multiple trajectories.

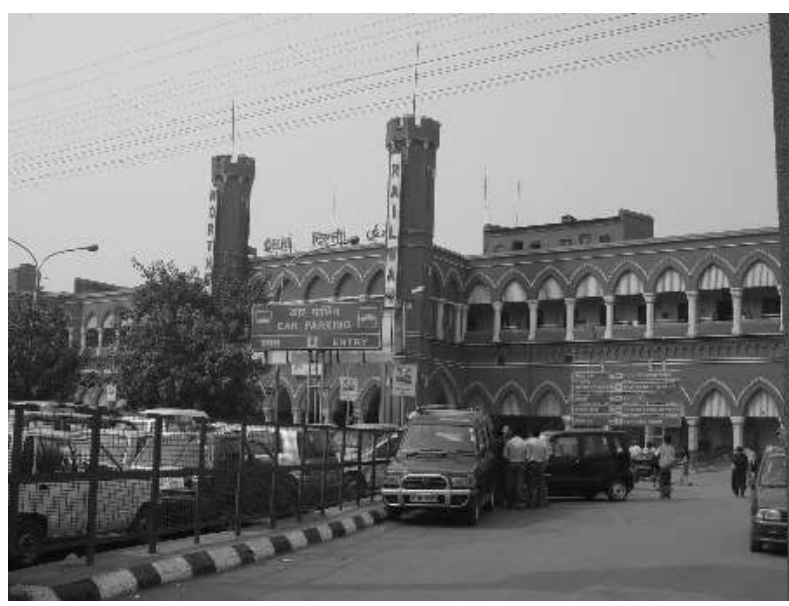

Figure 1. Delhi's industrial-utilitarian landscape with the Railway Station as the centre piece. (Image Source: Author)

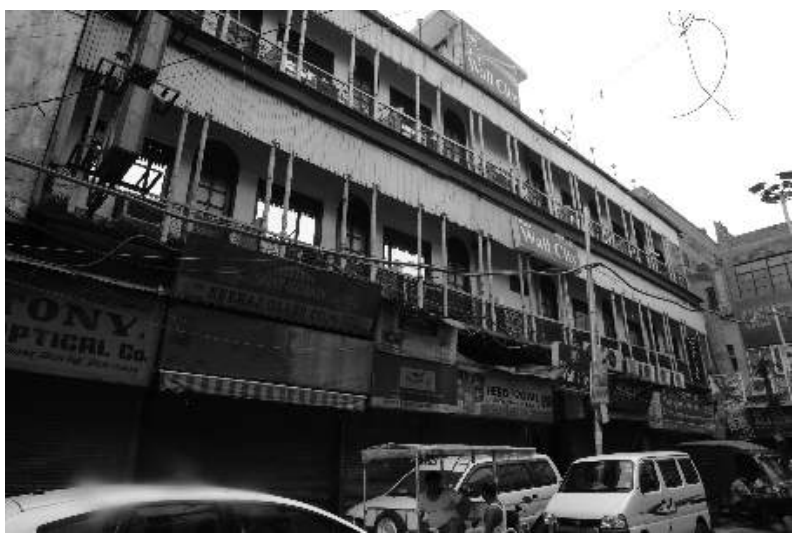

Figure 2. Remnants of 19th century Delhi streetscape, showing every day buildings with industrial technology (Image Source: Author)

The Subcontinent's architecture of the colonial era has been a popular subject of scholarship with the architectural patronage of the British Raj as well as princely India receiving academic attention (Bence-jones, Mark 1973,
Davies, Philip 1988, Morris, Jan and Winchester, Simon 1983, Nilsson, Sten 1968 \& Volwahsen, A. 2004). While the former included civic architecture like buildings for administration and public institutions like railway stations, hospitals, museums, colleges among others, the latter tended to be centered largely on princely India's personal building enterprise notably palaces and on commissioning of public works in keeping with the colonial state's post uprising modernization agenda (Fig. $3 \& 4$ ). Scholarship has tended to focus on a descriptive narrative that underscores the 'Splendour' of the architectural initiatives of both British architects who chose to set up practices in the Subcontinent and that of the PWD that was responsible for designing and executing a majority of works for the colonial regime in post uprising period. That the country had a long, living tradition of construction based on centuries old knowledge systems was ignored by the state, the most influential commissioner of architectural works. Likewise, it also escaped the notice of scholars as well until recently (Parimoo, Ratan 2015, Tillotson, Giles H. R. 1989 \& Vandal, P. and Vandal, S. 2006) F. S. Growse, a British civil servant, articulated the prevailing sentiment aptly, in the Preface of his 1885 publication, Indian Architecture of Today as Exemplified in New Buildings in the Bulandshahr District stating that the 'Superintending Engineers, in their annual reports to Government, are in the habit of stating that "Tahsildars and other non-departmental officials, from want of technical knowledge, cannot and do not execute original works, or even repairs, as they should be done," and therefore all local improvements ought to be carried out exclusively by the Public Works establishment' (Growse, F. S. 1885). He went onto to declare that 'If our Municipalities and District Boards were relieved from the incubus of "standard plans," and exhorted to encourage native talent by employing it in the design and execution of local improvements, the streets of our towns would soon assume a more pleasing appearance;' (Growse, F. S. 1885). Little attention was paid by the state to Growse's opinion as the Mistri, remained completely ignored as a contributor in building of a modern India even as he negotiated tradition and modernity in diverse ways. This attitude of neglect of traditional architectural practices is also reflected in the scholarship of colonial architecture, whose examination reveals that let alone the Mistri's enterprise, the colonial architectural enterprise has hardly been critically examined under the lens of modernity, until very recently (Hosagrahar, jyoti 2005 \& Scriver, Peter and Prakash, V. 2007). Further, the bulk of common place, everyday, utilitarian buildings commissioned largely by modest patrons and designed and built by Mistris has not been able to find a place either in the architectural discourse in general or in that of modernity in the context of the Subcontinent in particular, a gap that this paper hopes to fill. 


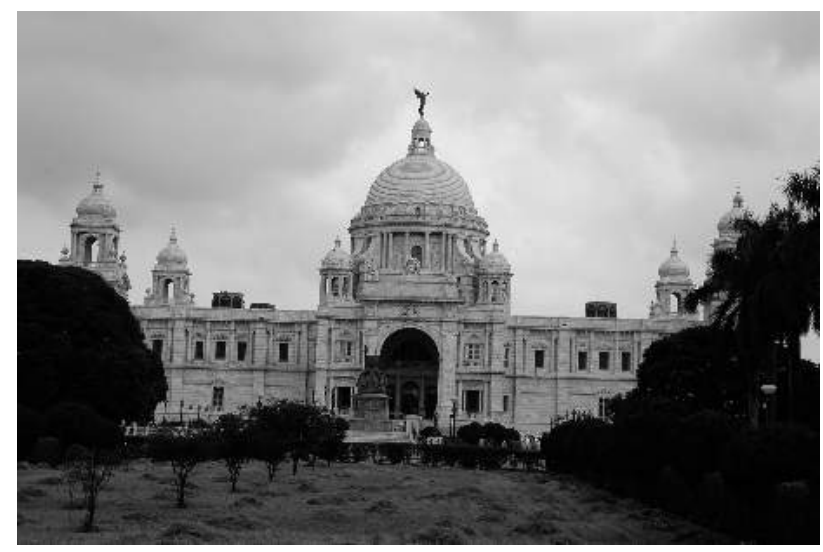

Figure 3. Victoria Memorial, Calcutta, showcasing the architectural exploits of the British Raj (Image Source: Author)

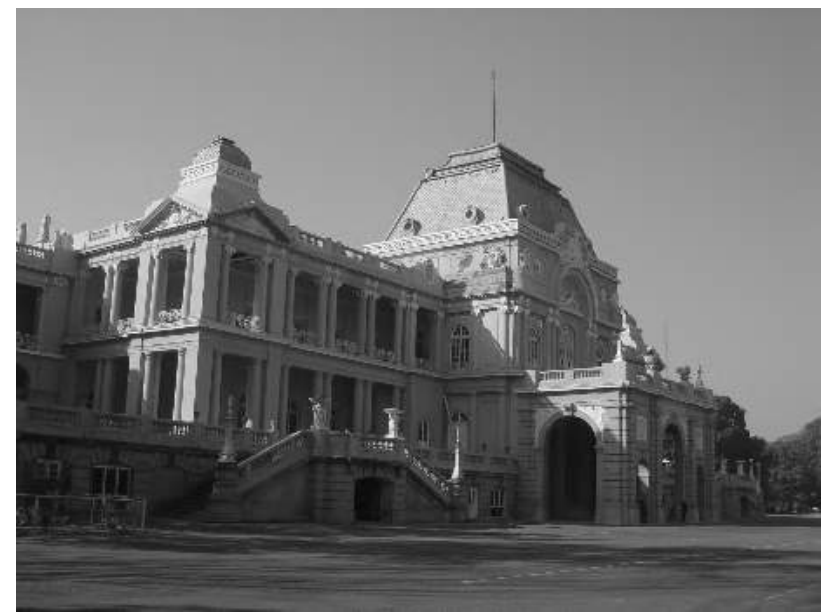

Figure 4. Jagatjit Palace, Kapurthala, built by the Maharaja of Kapurthala as his residence (Image Source: Author)

The paper examines the work of Gordon Sanderson who spoke of the value of the Indian architectural tradition and the contribution of the Mistri in evolving the architecture of a rapidly modernizing India. Among the scarce voices to take up cudgels for the promotion of traditional Indian architecture, Sanderson's opinion was disregarded by the colonial state that chartered the course of India's architecture based on political realities as reflected in the planning and building of the biggest, coeval, architectural enterprise of British India in the early decades of the $20^{\text {th }}$ century, New Delhi. It is argued that Sanderson's approach departed from that of other pro-craft lobbyists including Jacob, Havell, et al in that he advocated a form of modernity that drew on formally training the Mistri in the ways of the west, a practice that was largely non-existent as transmission of traditional building knowledge and skills was oral. Further, the Mistris created their own version of modernity by imitating, altering and adapting European fashions. Indeed, the colonial city became a receptacle for all versions of modernities that co-existed in an atmosphere marked by complexity and contradition.

\section{Sanderson's Survey of Modern Indian Buildings: a Critical Examination}

This section critically examines the role played by the various actors who contributed to the publication of the survey either directly or indirectly, namely the India Society, the commissioner of the project; the Government of India that directed ASI to undertake the work; its Consulting Architect, John Begg who wrote a note on the development of architecture in India and Gordon Sanderson, surveyor and author of the report. The work of compiling a compendium of modern Indian buildings was undertaken at the behest of the London based India Society that championed the cause of traditional Indian architecture. The project was executed by Sanderson on the orders of Government of India in 1911-12. While all the actors shared a concern about the future of Indian architecture, it would not be wrong to claim that opinions on how that future be shaped varied as discussed below.

It is worth underscoring that the timing of the project was significant. The year 1911-12 was a politically significant year as it marked the occasion of the third Delhi Durbar, a massive public show of British might, whose concluding day witnessed the announcement by none other than the incumbent British monarch, King George V, of the transfer of the capital of British India from Calcutta to Delhi (Irving, Robert G. 1981). The architectural implication of the announcement was significant as a new capital had to be planned and built on a site chosen on the Delhi plains. Both Sanderson and Begg had an opinion on the architectural style in which the buildings of the new capital were to be built and expressed it in no uncertain terms in the report even as it was contrary to that of the Government, the client of the New Delhi project.

The India Society, at who's urging the survey got underway, was founded in London in 1910 under the patronage of E. B. Havell, with the purpose of drawing attention to the traditional arts and crafts of the Indian Subcontinent. While appreciating the fact that India continued to have an 'unbroken tradition of design and craftsmanship handed down from remote antiquity', the Society was also well aware of the threat to this living, indigenous architectural tradition by the growing proclivity of 'English-educated classes in India' towards 'European fashions' as well as by the government's abettment of those craftsmen who 'merely imitate the commercial art of modern Europe' (Sanderson, G. 1913). Clearly, the Society was concerned about the influence of European ideas on Indian architecture that in its opinion were diluting the 
antiquity of the Mistris' skills. Concerned about the decline in the Subcontinent's traditional building skills following colonisation, the Society took upon itself to bring out an illustrated publication on what it described as 'modern Indian architecture and architectural decoration'. A letter written by its Honorary Secretory, T. W. Rolleston, dated 20 November, 1910, stated that the Society had been recently formed for the purpose of promoting the study and appreciation of Indian culture in all its aesthetic aspects' and wanted the support of the Government of India to 'collect material relating to the living traditions of Indian Art and Architecture'. The Society opined that while the colonial government in India had taken measures to 'assist archaeological research, the importance of investigating the principles and practice of the living art and craft of India has not received anything like adequate attention' (Sanderson, G. 1913). Further the letter stated the Society's inability to undertake this task on their own and therefore requested the government that the exercise be assigned to the 'Archaeological Department' whose 'surveyors while on tour' could 'photograph interesting types of modern Indian buildings' and to 'take notes of the names and addresses and local rates of remuneration of the principal craftsmen concerned in the designing and decoration of them'. The letter concluded by stating in no uncertain terms that the 'historical continuity of Indian architectural traditions is a matter of deepest interest to the student of archaeology,' and the compilation would be useful for 'promoting technical and art education in India' but did not specify how the latter would be achieved (Sanderson, G. 1913). While the Society's concerns were significant in that the colonial state had made no worthwhile attempt to record and investigate the traditional building skills of India, it also seemed at the same time, that it was viewing the architectural tradition, from the position of the pro-craft lobbyist, as a product of antiquity alone that would be marred if it began to accept contemporary novelties. Indeed, the Society failed to recognize that the livingness of the tradition was not from the antiquity perspective alone but the building craft also had the capacity to imitate, adopt, adapt as well as reject modernity. Sanderson's survey would validate the latter assessment.

The task of compiling the compendium was assigned to Gordon Sanderson (1887-1915), an architect by training, who was the Superintendent, Muhammadan and British Monuments, Northern Circle, Agra in the ASI. Sanderson served in India from 1911 to 1915 and during this tenure he was posted in Delhi to supervise the conservation of the city's several prominent historic monuments that were intended to be seamlessly integrated with the upcoming new capital of British India, New Delhi to establish the MughalBritish continum as part of state policy. He authored a guidebook to Delhi's Red Fort besides publishing satirical sketches of monuments to underscore what he perceived as the incompetence of the PWD (Sanderson, G. 1937). Following his demise a memorial by way of a white marble sundial was raised in Delhi's Qutub Complex, a historic site that was conserved under his supervision. Convinced of the capability of the Mistri, a position contrary to that of his peers not only in the ASI but also the PWD, Sanderson urged the British Government for greater involvement of Indian artisans and craftsmen in the ongoing works including the building of New Delhi. Needless to say, his recommendations were ignored. Sanderson was critical of the work of the PWD that overlooked the traditional building crafts of India as its engineers took up the task of making buildings on an unprecedented scale after the uprising. Already lobbying for a greater role for the Mistri in the building of a modern India, it would be fair to postulate that Sanderson was probably glad to be given the assignment on behalf of the India Society to survey and compile the compendium on modern Indian buildings.

Sanderson undertook the survey in 1911-12 under the supervision of John Marshall, the Director General of ASI. The survey was limited to cities in the northern part of the Subcontinent focusing on Delhi, cities in the United Provinces namely Agra, Allahabad and Lucknow, and cities in the Indian states namely Ajmer, Bhopal, Bikaner, Gwalior, Jaipur, Jodhpur and Udaipur. The findings were published by the government the following year in a book titled 'Types of Modern Indian Buildings at Delhi, Agra, Allahabad, Lucknow, Ajmer, Bhopal, Bikanir, Gwalior, Jaipur, Jodhpur and Udaipur, with notes on the craftsmen employed on their design and execution'. In the Foreword of the publication Sanderson clarified that the work dealt with the 'local architecture of a small portion of northern India, and that but briefly' (Sanderson, G. 1913). He went on to explain the circumstances under which the work was executed. The selection of sites was based on replies received to his query sent out to officials of the PWD as well as the Departments of Revenue and Agriculture of Punjab and United Provinces whether they 'knew of any buildings of the type instanced in the letter of the India Society' so that he could 'see and photograph them on his next visit'. Sanderson received twenty-one replies to his query stating that 'there were no such buildings' while seven replies mentioned the existence of modern Indian buildings at 'Agra, Delhi, Lucknow, Allahabad, Muttra, Amritsar and Saharanpur' (Sanderson, G. 1913). That such replies were indeed received is hardly surprising because these kind of buildings simply did not qualify as architecture in the state's viewpoint and were thus not entitled to any kind of official documentation, let alone being regarded as specimens of modernity. The selection of buildings from the Rajputana 
states resulted from Sanderson's visit for the purpose of collecting 'antiquities for the Historical and Archaeological Loan Exhibition' to be held in Delhi on the occasion of the third Delhi Durbar. Indeed, the Durbar by Sanderson's own admission left him with an 'exceptionally heavy' workload that prevented him from giving 'as much time to the project as I could have wished'. In his opinion the survey should been more expansive in terms of regional representation of building types but owing to the urgency as expressed by the Government, on account of 'the importance attaching to the indigenous architecture in connection with the building of the new Capital of Delhi', he was 'instructed' to 'prepare the report without delay'(Sanderson, G. 1913). Further, Sanderson also outlined the difficulty he faced in collating the second aspect of information that the India Society sought, i.e. the details regarding the craftsmen engaged in making the buildings he surveyed. Not only did the state officials who accompanied him to site when he surveyed the buildings scoffed at the idea of seeking the details of the craftsmen but the latter themselves were not forthcoming with information and regarded Sanderson with suspicion. This state of affairs allows one to infer that the state had absolute disregard for the skills of the craftsmen, Sanderson's viewpoint notwithstanding. Further, the craftsmen themselves through years of state indifference had lost their sense of self worth even as they negotiated European influences on their own terms.

Sanderson surveyed the following types of buildings: Dharamshalas (rest houses), temples, mausoleums, residences, printing press, guest house, shops, courts, streetscapes and mosques. The choice of buildings was an outcome of information he had sought from the government departments namely PWD, Revenue and Agriculture. The selection was also influenced by the Society's brief to include buildings built by 'skilled master builders' such as 'temples, mosques, travellers' rest houses, and bathing tanks, \& c., as well as domestic buildings, in the traditional style of Indian art' (Sanderson, G. 1913). Each building included in the survey had a description written by Sanderson accompanied by at least one photograph, that he collated on site. Sanderson summarized his findings by stating that 'the traditions of design and craftsmanship are in a state of transition' that he attributed to the India Society's assessment i.e. the influence from Europe and its acceptance by Indians who had been acculturated into the western tradition. Indeed, Sanderson's stance was similar to that of the Society as he was also critical of the use of both design elements and industrial technology of European origin by the craftsmen in the buildings he surveyed. While describing two Dharamshalas in Delhi, Laxmi Narain Dharamshala (Fig. 5) and Lala Chunna Mal's Dharamshala, (the latter today popularly referred to as Bagh Deewar Dharamshala), Sanderson opined that while their design was the outcome of a 'thinking mind' and a 'praiseworthy endeavour to evolve a new expression', the impact was marred by the use of technology i.e. 'cast and corrugated iron' (Fig. 6) on the first floor even offering an explanation that perhaps the patrons had 'run out of money' and were therefore compelled to use modern materials instead of 'what was originally intended to be in stone' (Sanderson, G. 1913) (Fig. 7, 8). To attribute the use of industrial technology as a desperate cost cutting measure rather than innovation by the Mistri reflects Sanderson's viewpoint that was in alignment with that of the pro-craft lobby as well as the India Society. Further, in the case of an under construction memorial, called Swamiji Maharaj Samadh, at Agra, Sanderson observed that iron girders were lying on the construction site and concluded that they were perhaps unfit for use structurally and would have to be sold as scrap. Furthermore, in the case of Bikaner, Sanderson commented that the residences of a particular community 'are fitted within with electric light, electric fans, and other appurtenances of modern comfort' (Sanderson, G. 1913). He justified the light and fan as being essential for comfort but was critical of the use of other European imports like fan-lights and upholstery that in his opinion reflected the 'attitude of the Indian towards European art. He has not been educated to it and does not know what to take and what to reject' (Sanderson, G. 1913). Sanderson concluded his report by offering an explanation for what he called 'decadence of the architecture of Northern India' that went beyond the India Society's assessment that attributed it to European influences. He asserted that the Indian building tradition had gone into a steady decline during the late Mughal period from which it never recovered and the outcome was the 'unhappy erections that are so frequently met with in the "average Cantonment" Station' (Sanderson, G. 1913). He further observed that the craftsmen, who 'have had no training, and are of the humblest class' should not be blamed since they have been exposed to 'buildings of the most mediocre architectural quality, and at the worst, they have been striving after an ideal and endeavouring to express in their buildings the results of European influence' (Sanderson, G. 1913). In respect of the Rajputana states, Sanderson's observation is worth reporting as it clearly establishes that he, like the Society, for whom he was undertaking the work, was of the view that any form of European influence that the Mistri chose to adopt detracted from the purity of the building tradition. He reported that in the Rajputana states 'Indian life is very much the same as it was three or four centuries ago, and architecture is still a living art. In spite of the railways, telegraphs, and the visits their rulers and nobles pay so often to western lands, it is almost purely native, and the building traditions are still unbroken'(Sanderson, G. 1913). He went on to caution 
that places like Rajputana needed to be shielded from the mediocrity that could be seen elsewhere. However, sounding optimistic, Sanderson stated that the 'improvement' in architectural taste of craftsmen could result from 'education established on the right lines' and emphasized that the training of those in the building profession, 'of average and low ability' be done by focussing on 'construction and practical modern considerations' as opposed to mere 'draftsmanship'(Sanderson, G. 1913). Likewise, in the context of Mistris he elaborated that 'sound planning and practical construction are more important than the façade and its treatment. It is much easier to copy than to think,' and warned against 'dwelling too constantly on features of historical styles or adapting misunderstood European forms of design'. Sanderson concluded his report by stating that 'excellent master craftsmen' could not be brought directly 'under the influence of education' therefore 'it is for the architect to guide them' (Sanderson, G. 1913). A task that was easier said than accomplished as there existed a schism between the professional i.e. architect and the unschooled Mistri since the onset of colonial rule in the Subcontinent. The state's continued indifference had only widenend it with the passage of time with no thought given to evolving mechanisms by which this gap could be addressed, the plea of the pro-craft lobby notwithstanding.

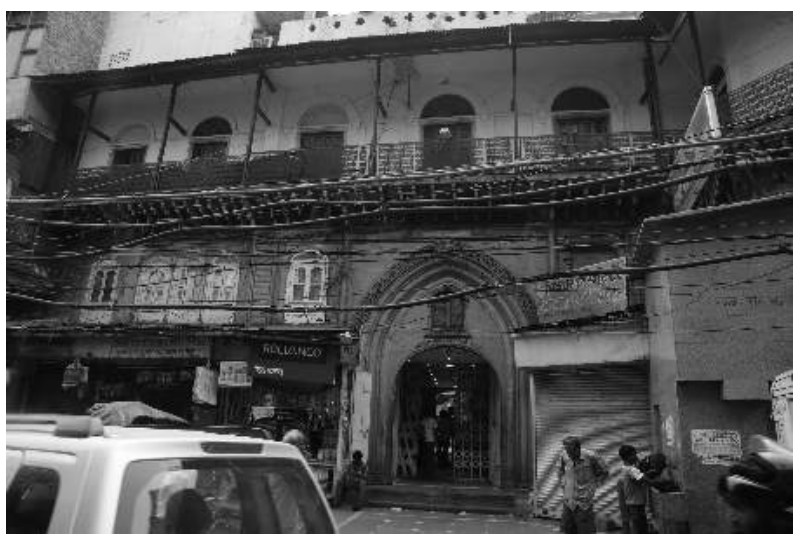

Figure 5. Laxmi Narain Dharamshala, Delhi, exterior view from the street with use of cast iron columns on the first floor (Image Source: Author)

Sanderson's report also carried a 'Note on the Development of Indian Architecture' that was written by John Begg, architectural consultant to the colonial government of the day. While Begg's opening remarks talked about the country's rich architectural heritage both in terms of buildings and craft tradition, he observed that the country had 'hardly begun as a nation to develop a modern architecture' (Sanderson, G. 1913). He further stated that while the country had modernized its transportation, irrigation, and other allied infrastructure, under the watchful eye of the British, the same attention had not been paid to the development of architecture both by the government and the Indians themselves who were hardly training to become architects. Begg stressed that instead of looking towards the government to tackle this issue, it would be best if the Indians themselves who he declared, were anxious to have a 'national architecture' would 'not stop short with enthusiasms and demands, but concretes itself into men and work'. Begg stated that Sanderson's survey was a testimony of the 'Government's sympathy in the matter'. He urged the government to chalk out and 'declare a definite architectural policy for India; just as we have thought out a railway policy and an educational policy'(Sanderson, G. 1913). He argued that the living tradition is an artistic asset of such incalculable value that we cannot afford to allow it to die out; that it is worth re-awakening, even though the complete process should be lengthy and interim results not acceptable, may be, to all.' He believed that India's architectural tradition could be made to 'supply all the complex needs of modern India in a manner in conformity at once with sound business principles and with the canons of true art, (...)' and that a 'developed Indian architecture' would result in 'buildings that are modern, convenient and economical'(Sanderson, G. 1913). Offering a solution as to how this might be turned into a reality, Begg suggested 'opening up of the profession of the architect to the youth of India, to whom it has hitherto seems to have its doors closed.' Further, he elaborated that in the absence of schools where architects could be trained in India, Indian youth could be sent to Britain to be 'throughly grounded in the principles of architectural design' as these are understood in the west. Begg hoped that upon their return to India these architects would design for the 'complex problems of modern life in India, drawing their inspiration from the best examples of old work and traditional work in the country' thus resulting in an 'indigenous architecture at once modern and distinctively Indian, carrying on the traditions of art and putting renewed life into the crafts of building' (Sanderson, G. 1913). Begg then went onto echo Sanderson's view about the employment of the traditional Indian architectural style in the building of New Delhi arguing 'why should a western manner be held to type most fittingly the spirit of the Government of India?' and that 'it is not impossible for the European architect to work in the spirit of this great country' (Sanderson, G. 1913).

The Government of India did not agree with both Sanderson and Begg and noted in the Preface of the publication that the 'opinions expressed by Mr. Begg and Mr. Sanderson are personal to themselves and the Government of India is in no way committed to the approval of their views' (Sanderson, G. 1913). Indeed, the government indicated its intent very explicitly by appointing in 1912 Edwin Landseer 
Lutyens as the architect planner of New Delhi. That Lutyens had nothing but disdain for traditional Indian architecture, only furthered the colonial regime's agenda to marginalise the Mistri (Irving, Robert G. 1981). Further, the state's stance, driven more by political compulsion rather than the need for a conscious expression of European style modernity in New Delhi's buildings, went on to ensure that neither Sanderson's Mistri nor Begg's European architect with a sympathy for traditional Indian architecture were to have a say in the building of the new capital of British India. New Delhi built in the classical style with some sprinkling as it were of elements of Indian origin, the latter more out of political correctness than any love for the Indian tradition, became the most powerful symbol of architecture in the British Indian empire in the early decades of the $20^{\text {th }}$ century.

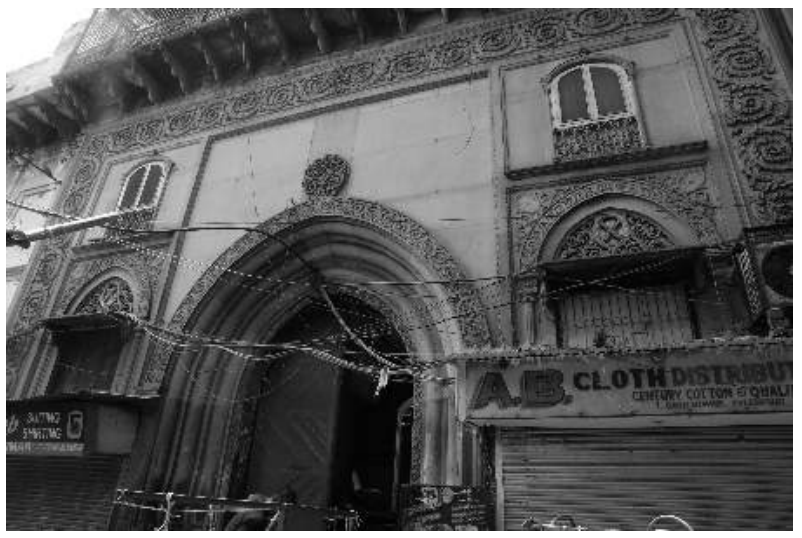

Figure 6. Bagh Deewar Dharamshala, Delhi, exterior view from the street (Image Source: Author)

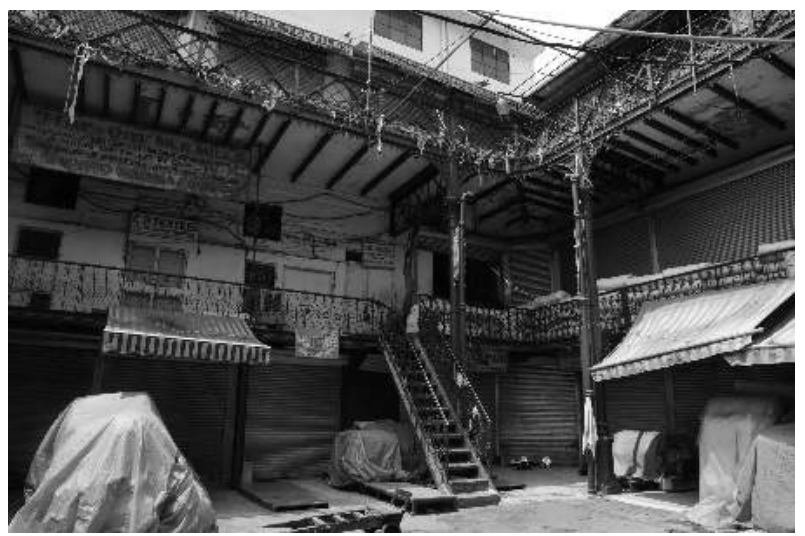

Figure 7. Bagh Deewar Dharamshala, Delhi, interior view with cast iron columns (Image Source: Author)

\section{Conclusion}

Twenty one years after Sanderson's survey, Claude Batley, published a collection of measured drawings 'to meet a need which everyone who has set out to study the elements of Indian Architecture must have felt' that contained not only details of monuments but also 'smaller domestic architecture, from which, perhaps, the most useful inspiration may be gleaned by architects in connection with their practice in the India of to-day' (Batley, Claude 1960). The survey included among others specimens of residences from different parts of the country such as Baroda, Madura, Nasik and Poona that Batley hoped would serve as a reference for practicing architects much like Jacob had hoped through his Jeypore Portfolio of Architectural Details. Jacob had documented and published a compendium of architectural details from an array of historic buildings across the state of Jeypore in the late $19^{\text {th }}$ and early $20^{\text {th }}$ century (Jacob, S. S. 1890). The attempts of Jacob, Growse and Batley to produce what they envisioned to be useful compilations on Indian architecture, and the views of government officers like Begg and Sanderson, not withstanding, it is evident that the state did not wish to chalk out a framework for the development of modern Indian architecture. In such a scenario the response to modernity tended to be varied as each actor from the patron, i.e. state or private individuals to the designer and builder, i.e. the state engineer, architect to the Mistri chose to respond in their own way resulting in a hybrid expression. There were buildings patronized by the state that were trapped in $19^{\text {th }}$ century historicism and eclecticism in terms of stylistic expression even in the early $20^{\text {th }}$ century. While there were others that chose to negotiate modernity and tradition through uninformed imitation to informed adaptation and assimilation and everything else in between. The outcome of these various practices was a highly hybrid urban landscape that characterized cities across the Indian Subcontinent.

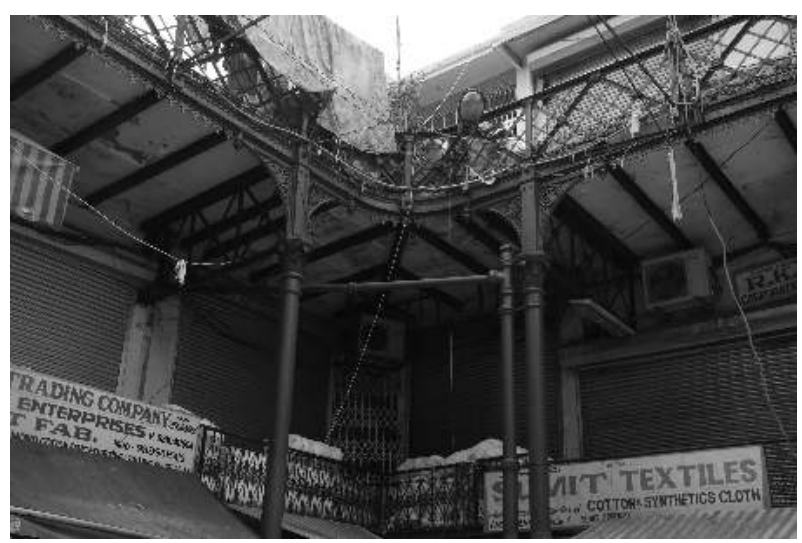

Figure 8. Bagh Deewar Dharamshala, Delhi, detail of cast iron structural support system (Image Source: Author)

To not acknowledge the building corpus that resulted from these circumstances as products of modernity reflects a lack of ability to look at modernity beyond the European 
lens. Further, given the fact that a large number of these buildings continue to remain in our cities and are falling prey, by way of vandalism or even complete destruction, to the pressures of contemporary development, it is incumbent upon both the state and the citizenry to recognize their worth as modern heritage. Perhaps it is time that a survey of the kind that Sanderson undertook more than a century ago be undertaken yet again, no longer confined in its territorial jurisdiction as it did in the past but be more expansive to cover the entire country to make inventories and document this vast corpus so that a framework for its conservation can be prepared. Such an intervention will not only be in keeping with the mandate of global organizations like the DOCOMOMO but will also bridge the gap that exists in the country's narrative on the development of modern architecture.

\section{References}

[1] APPADURAI, ARJUN (1996) Modernity at Large: Cultural Dimensions of Globalisation. Minneapolis: University of Minnesota Press.

[2] BATLEY, CLAUDE (1960) The Design Development of Indian Architecture. Bombay: D. B. Taraporevala Sons and Co. Ltd. Reprint.

[3] BENCE-JONES, MARK(1973) Palaces of the Raj. London: Allen and Unwin.

[4] BHABA, HOMI K. (1994) The Location of Culture. New York: Routledge.

[5] COPLAND, IAN (1997) The Princes of India in the Endgame of Empire, 1917-1947. Cambridge: Cambridge University Press.

[6] DAVIES, PHILIP (1988) Splendours of the Raj British Architecture in India, 1660-1947. London: Penguin Books, Reprint.

[7] GAONKAR, DILIP P. (2001) On Alternative Modernities. InDilipParameshwar Gaonkar (Ed.), Alternative Modernities(pp. 1-23). London: Duke University Press.

[8] GLOVER, WILLIAM J. (2007) Making Lahore Modern: Constructing and Imagining a Colonial City. Minneapolis: University of Minnesota Press.

[9] GROWSE, F. S. (1885) Indian Architecture of Today as Exemplified in New Buildings in the Bulandshahr District. Part I, Allahabad: North-Western Provinces and Oudh Government Press.

[10] GUPTA, NARAYANI(1981) Delhi Between Two Empires: 1803-1931 - Society, Govt. \& Urban Growth. Delhi: Oxford University Press.
[11] HAVELL, E. B. (1913) Indian Architecture, its Psychology, Structure, and History from the First Muhammadan Invasion to the Present Day. London: John Murray.

[12] HOSAGRAHAR, JYOTI (2001) 'Mansions to Margins: Modernity and the Domestic Landscapes of Historic Delhi 1847-1910', Journal of the Society of Architectural Historians, 60:1, 26-45.

[13] HOSAGRAHAR, JYOTI (2005) Indigenous Modernities: Negotiating Architecture and Urbanism. New York: Routledge.

[14] IRVING, ROBERT G. (1981) Indian Summer: Lutyens, Baker and Imperial Delhi. New Haven: Yale University Press.

[15] JACOB, S. S. (1890) Jeypore Portfolio of Architectural Details. London: Bernard Quatrich and Sons Co.

[16] KLEIN, IRA (2000) 'Materialism, Mutiny and Modernization in British India', Modern Asian Studies, 34(3), 545-80.

[17] METCALFE, THOMAS R. (1989) An Imperial Vision: Indian Architecture and Britain's Raj. London: Faber and Faber.

[18] MORRIS, JAN AND WINCHESTER, SIMON (1983) Stones of Empire - The Buildings of the Raj. Oxford: Oxford University Press.

[19] NILSSON, STEN (1968) European Architecture in India 1750-1850. London: Faber.

[20] OLDENBURG, VEENA T. (1984) The making of Colonial Lucknow: 1856-1877. New Jersey: Princeton University Press.

[21] PANDEY SHARMA, J. (2015). Disciplining Delhi: The 1857 uprising and remodelling of the urban landscape. In JoAnne Mancini and Keith Bresnahan (Ed.), Architecture and Armed Conflict: The Politics of Destruction (pp. 131-46). New York: Routledge.

[22] PARIMOO, RATAN(2015) 'Revival of Indian Architecture: The debate and the plight of the Mistri', Studies in Humanities and Social Sciences, 12:1, 45-67.

[23] RALEIGH, SIR THOMAS (1906) Lord Curzon in India: Being a Selection from His Speeches as Viceroy and Governor-General of India 1898-1905. London: Macmillan and Co. Limited.

[24] SACHDEV, V. (2012) 'Negotiating Modernity in the Princely State of Jaipur South Asian Studies, 28:2, 17181. doi:10.1080/02666030.201

[25] SANDERSON, G. (1913) Types of Modern Indian Buildings at Delhi, Agra, Allahabad, Lucknow, Ajmer, Bhopal, Bikanir, Gwalior, Jaipur, Jodhpur and Udaipur, with notes on the craftsmen employed on their design and execution. Allahabad: Government Press. 
[26] SANDERSON, G. (1937) The Red Fort, Delhi: A Guide to the Buildings and Gardens. Delhi: Archaeological Survey of India.

[27] SANDES, E. W. C. (1935) The Military Engineer in India. Vol. II. Chatham: Institute of Royal Engineers.

[28] SCRIVER, PETER AND PRAKASH, V. (2007). (Ed.) Colonial Modernities: Building, Dwelling and Architecture in British India and Ceylon. New York: Routledge.
[29] TILLOTSON, GILES H. R. (1989) The Tradition of Indian Architecture: Continuity, Controversy and Change since 1850. New Haven: Yale University Press.

[30] VANDAL, P. AND VANDAL, S. (2006) The Raj, Lahore and Bhai Ram Singh. Lahore: NCA Publication.

[31] VOLWAHSEN, A. (2004) Splendours of Imperial India-British Architecture in the 18th and 19th Centuries. London: Prestel-Verlag. 